\title{
cGMP Accumulation Causes Photoreceptor Degeneration in CNG Channel Deficiency: Evidence of cGMP Cytotoxicity Independently of Enhanced CNG Channel Function
}

\author{
Jianhua Xu, ${ }^{1}$ Lynsie Morris, ${ }^{1}$ Arjun Thapa, ${ }^{1}$ Hongwei Ma, ${ }^{1}$ Stylianos Michalakis, ${ }^{2}$ Martin Biel, ${ }^{2}$ Wolfgang Baehr, ${ }^{3}$ \\ Igor V. Peshenko, ${ }^{4}$ Alexander M. Dizhoor, ${ }^{4}$ and Xi-Qin Ding ${ }^{1}$ \\ ${ }^{1}$ Department of Cell Biology, University of Oklahoma Health Sciences Center, Oklahoma City, Oklahoma 73104, ${ }^{2}$ Center for Integrated Protein Science \\ Munich and Department of Pharmacy-Center for Drug Research, Ludwig-Maximilians-Universität München, 80539 Munich, Germany, ${ }^{3}$ John A. Moran \\ Eye Center, University of Utah, Salt Lake City, Utah 84132, and ${ }^{4}$ Department of Basic Sciences and Pennsylvania College of Optometry, Salus University, \\ Elkins Park, Pennsylvania 19027
}

Photoreceptor cyclic nucleotide-gated (CNG) channels regulate $\mathrm{Ca}^{2+}$ influx in rod and cone photoreceptors. cGMP, the native ligand of the photoreceptor CNG channels, has been associated with cytotoxicity when its levels rise above normal due to defects in photoreceptor phosphodiesterase (PDE6) or regulation of retinal guanylyl cyclase (retGC). We found a massive accumulation of cGMP in CNGA3deficient retina and investigated whether cGMP accumulation plays a role in cone degeneration in CNG channel deficiency. The time course study showed that the retinal cGMP level in $\mathrm{Cnga3}^{-1-} ; \mathrm{Nrl}^{-1-}$ mice with CNGA3 deficiency on a cone-dominant background was sharply increased at postnatal day 8 (P8), peaked around P10-P15, remained high through P30-P60, and returned to near control level at P90. This elevation pattern correlated with photoreceptor apoptotic death, which peaked around P15-P20. In $\mathrm{Cnga3}{ }^{-1-} ; \mathrm{Gucy} 2 e^{-1-}$ mice lacking retGC1, cone density and expression levels of cone-specific proteins were significantly increased compared with $\mathrm{Cnga3}{ }^{-/-}$, consistent with a role of cGMP accumulation as the major contributor to cone death caused by CNG channel deficiency. The activity and expression levels of cGMP-dependent protein kinase G (PKG) were significantly increased in $\mathrm{Cnga3}^{-I-} ; \mathrm{Nrl}^{-I-}$ retina compared with $\mathrm{Nrl}^{-I-}$, suggesting an involvement of PKG regulation in cell death. Our results indicate that cGMP accumulation in photoreceptors can itself exert cytotoxic effect in cones, independently of CNG channel activity and $\mathrm{Ca}^{2+}$ influx.

\section{Introduction}

Photoreceptor cyclic nucleotide-gated (CNG) channels play a central role in phototransduction. In darkness, the channel is kept open by cGMP, maintaining a steady $\mathrm{Na}^{+}$and $\mathrm{Ca}^{2+}$ influx. Light induces hydrolysis of cGMP by photoreceptor phosphodiesterase (PDE6), resulting in closure of the channel and hyperpolarization of the cell (Kaupp and Seifert, 2002). Mutations in genes encoding the cone channel subunits CNGA3 and CNGB3 are associated with achromatopsia and cone dystrophies (Kohl et al., 1998). There are $\sim 80$ and 40 mutations in CNGA3 and

Received Feb. 27, 2013; revised July 10, 2013; accepted Aug. 11, 2013.

Author contributions: J.X., S.M., M.B., W.B., A.M.D., and X.-Q.D. designed research; J.X., L.M., A.T., H.M., and I.V.P. performed research; J.X., L.M., A.T., H.M., and I.V.P. analyzed data; J.X., S.M., W.B., A.M.D., and X.-Q.D. wrote the paper.

This work was supported by grants from the National Center for Research Resources (P20RR017703), the National Eye Institute (P30EY12190, R01EY019490, R01EY08123, R01EY019298, and R01EY011522), the Oklahoma Center for the Advancement of Science \& Technology, and the Deutsche Forschungsgemeinschaft. We thank Drs. Anand Swaroop, Jan De Vente, Cheryl Craft, Muna Naash, and Jonathan Lytton for providing $\mathrm{Nrl}^{-1-}$ mouse line and antibodies for CGMP, M-opsin, CAR, S-opsin, and NCKX2.

The authors declare no competing financial interests.

Correspondence should be addressed to Xi-Qin Ding, 940 Stanton L. Young Boulevard, BMSB 553, Oklahoma City, OK 73104. E-mail: xi-qin-ding@ouhsc.edu.

J. Xu's present address: NPFPC Laboratory of Contraception and Devices, Shanghai Institute of Planned Parenthood Research, 2140 Xietu Road, 200032 Shanghai, China.

DOI:10.1523/JNEUROSCI.0909-13.2013

Copyright $\odot 2013$ the authors $\quad 0270-6474 / 13 / 3314939-10 \$ 15.00 / 0$
CNGB3, respectively, and these mutations account for $75 \%$ of achromatopsia cases.

Loss of cone function and cone degeneration have been documented in patients with CNG channel mutations (Thiadens et al., 2010). The retinal phenotype has also been characterized in $\mathrm{Cnga3}^{-1-}$ and $\mathrm{Cngb3}^{-1-}$ mice (Biel et al., 1999; Ding et al., 2009), and in mouse lines with CNG channel deficiency in a cone-dominant background (produced by elimination of the rod-specific neural retina leucine zipper transcriptional factor, $\mathrm{Nrl}$ ), i.e., $\mathrm{Cnga3}^{-1-} ; \mathrm{Nrl}^{-1-}$ and $\mathrm{Cngb3}^{-1-} ; \mathrm{Nrl}^{-1-}$ mice (Thapa et al., 2012). The $\mathrm{Cnga3}^{-/-}$and $\mathrm{Cnga3}^{-1-} ; \mathrm{Nrl}^{-1-}$ mice lack cone function and display early onset, progressive cone degeneration (Biel et al., 1999; Michalakis et al., 2005; Thapa et al., 2012).

Synthesis and decay of cGMP in the photoreceptor is controlled by retinal guanylyl cyclase (retGC) and PDE6, respectively. The cGMP synthesis regulation is mediated via the calcium binding guanylyl cyclase-activating proteins (GCAPs). GCAPs activate retGC (Dizhoor et al., 1994; Olshevskaya et al., 2012) when intracellular $\mathrm{Ca}^{2+}$ becomes low after illumination and closure of the channels following the hydrolysis of cGMP by lightactivated PDE6. Abnormally high rates of cGMP synthesis or abnormally low rates of its hydrolysis have been known to trigger photoreceptor death by naturally occurring and transgenically expressed mutations affecting activities of PDE6 or retGC (Bowes et al., 1990; Woodruff et al., 2007). Drastic elevation of cGMP 
occurs in the retinas of $r d 1 / r d 1$ mice lacking rod PDE6 $\beta$-subunit (Bowes et al., 1990). The death of rods in $r d 1 / r d 1$ mice is believed to associate with massive opening of CNG channel and subsequent raise in intracellular $\mathrm{Ca}^{2+}$ levels, because it can be slowed by calcium channel blockers (Frasson et al., 1999) and rod channel deletion (Paquet-Durand et al., 2011). Rod death in mice expressing GCAP1 mutants causing human dominant cone-rod dystrophy results from activation of retGC in the dark, which also leads to accumulation of cGMP and $\mathrm{Ca}^{2+}$ in rod outer segments (Woodruff et al., 2007).

To explore the mechanism(s) of photoreceptor degeneration caused by CNG channel deficiency, we examined retinal cGMP levels in $\mathrm{Cnga3}^{-1-} ; \mathrm{Nrl}^{-1-}$ mice and found a nearly 25 -fold elevation compared with the $\mathrm{Nrl}^{-1-}$ controls (Thapa et al., 2012). This work tested whether the $\mathrm{Cnga3}^{-1-}$ cone degeneration could directly result from accumulation of cGMP, and we demonstrated that cGMP accumulation can produce cytotoxic effect in cones even when the influx of $\mathrm{Ca}^{2+}$ through the CNG channel is suppressed.

\section{Materials and Methods}

Mice, antibodies, and other materials. The $\mathrm{Cnga3}^{-1-}$ and Gucy2e $e^{-1-}$ mouse lines in a C57BL/6 background were generated as described previously (Biel et al., 1999; Yang et al., 1999). The $\mathrm{Nrl}^{-1-}$ mouse line in a C57BL/6 background (Mears et al., 2001) was provided by Dr. Anand Swaroop (National Eye Institute, Bethesda, MD). The $\mathrm{Nrl}^{-1-}$ mouse line is a commonly used cone-dominant model for studies of cone cell biology and disease. NRL is a basic-motif leucine zipper transcription factor essential for the normal development of rods. Mice lacking the $\mathrm{Nrl}$ gene have no rods, but have increased numbers of S-cones, functionally manifested as a loss of rod function coupled with supernormal cone function (Mears et al., 2001). Morphologically, $\mathrm{Nr}^{-1-}$ photoreceptors have a cone-like nucleus, short and disorganized outer segment, and frequently form rosette-like structures in the retina (Mears et al., 2001). Electrophysiological studies demonstrate the expression of functional S- and M-opsins (Daniele et al., 2005; Nikonov et al., 2005), whereas gene expression studies confirm the transformation of all rods into cones in $\mathrm{Nrl}^{-1-}$ retinas (Yoshida, 2004). As a unique mammalian cone-dominant model, $\mathrm{Nrl}^{-1-}$ mouse line has been used for the study of cone function and protein activity including cone CNG channel (Farjo et al., 2006; Matveev et al., 2008; Thapa et al., 2012). The $\mathrm{Cnga3}^{-1-} ; \mathrm{Nrl}^{-1-}$ (Thapa et al., 2012) and $\mathrm{Cnga3}^{-1-}$;Gucy2e $e^{-1-}$ mouse lines were generated by cross-mating. Wild-type mice (C57BL/6 background) were purchased from Charles River Laboratories. Experiments were performed using mice of either sex. All mice were maintained under moderately dim cyclic ( $12 \mathrm{~h}$ light/dark) light conditions; cage illumination was $\sim 7$ foot-candles ( $\sim 75$ lux) during the light phase of the cycle. All animal maintenance and experiments were approved by the local Institutional Animal Care and Use Committee (Oklahoma City, $\mathrm{OK}$ ) and conformed to the guidelines on the care and use of animals adopted by the Society for Neuroscience and the Association for Research in Vision and Ophthalmology.

Rabbit antibodies against retGC1, retGC2, GCAP1, and GCAP2 were generated as described previously (Makino et al., 2008). Sheep anticGMP antibody was provided by Dr. Jan De Vente (Maastricht University, Maastricht, Netherlands). Rabbit antibodies against mouse M-opsin and cone arrestin (CAR) were provided by Dr. Cheryl Craft (University of Southern California, Los Angeles, CA). Rabbit anti-S-opsin antibody was provided by Dr. Muna Naash (University of Oklahoma Health Sciences Center, Oklahoma City, OK). Rabbit anti-NCKX2 antibody was provided by Dr. Jonathan Lytton (University of Calgary, Calgary, Canada). Rabbit anti-Gnat2 antibody was purchased from Santa Cruz Biotechnology (catalog \#sc-390), rabbit anti-PDE6C antibody was obtained from Abgent (catalog \#AP9728c), rabbit anti-PKGI antibody was purchased from Cell Signaling Technology (catalog \#3248), and mouse anti$\beta$-actin antibody was obtained from Abcam (catalog \#ab6276). Horseradish peroxidase (HRP)-conjugated anti-rabbit and anti-mouse secondary antibodies were purchased from Kirkegaard \& Perry Laboratories. Fluorescent goat anti-rabbit, goat anti-mouse, and donkey antisheep antibodies were purchased from Invitrogen. All other reagents were purchased from Sigma, Bio-Rad and Invitrogen.

cGMP ELISA. cGMP level in the retinal lysate was measured by ELISA using the cyclic GMP Complete Kit (Assay Designs). Briefly, dissected retinas were homogenized in $0.1 \mathrm{M} \mathrm{HCl}$. The acidic supernatants were used and the assays were performed per the manufacturer's instructions. The absorbance at $405 \mathrm{~nm}$ was measured with SpectraMax 190 Microplate Spectrophotometer (Molecular Devices). Each reaction was performed in duplicate and results are an average of three to four independent experiments using retinas prepared from five to eight mice.

$P D E$ activity assay. Retinal homogenates were subjected to direct sunlight for $10 \mathrm{~s}$ on ice and then assayed under bright incandescent illumination ( $>400$ lux). Retinas collected on ice under dim red illumination (four per $1.5 \mathrm{ml}$ Eppendorf tube) were frozen at $-70^{\circ} \mathrm{C}$, thawed on ice, and homogenized on ice with motor-driven pestle in $300 \mu$ l of $120 \mathrm{~mm}$ $\mathrm{KCl}, 60$ mм MOPS-KOH, pH 7.2,10 mм NaCl, 2 mм DTT, 5 mм MgCl , and $30 \mu \mathrm{g} / \mathrm{ml}$ aprotinin. The reaction in $25 \mu \mathrm{l}$ assay containing $12.5 \mu \mathrm{l}$ of the retinal homogenate was started by adding $12.5 \mu$ lof the mix containing $2 \mathrm{~mm}$ GTP, $2 \mathrm{~mm} \mathrm{5'-GMP,} 2 \mathrm{~mm}$ cGMP, and $\sim 0.1 \mu \mathrm{Ci}$ of $[8-$ ${ }^{3} \mathrm{H}$ ]cGMP (PerkinElmer). After incubation for $10 \mathrm{~min}$ at $30^{\circ} \mathrm{C}$, when $<15 \%$ of the cGMP substrate was converted to the $5^{\prime} \mathrm{GMP}$, the reaction was stopped by heating the samples for $2 \mathrm{~min}$ at $95^{\circ} \mathrm{C}$ and the samples were then transferred on ice. After centrifugation for $5 \mathrm{~min}$ at $10,000 \times \mathrm{g}$, $5 \mu \mathrm{l}$ aliquots from each assay were applied on fluorescent-back polyethylenimine cellulose thin-layer chromatography plates (Merck) and developed in $0.2 \mathrm{M} \mathrm{LiCl}$ at room temperature. The spots containing cGMP and $5^{\prime} \mathrm{GMP}$ were excised, eluted in $0.5 \mathrm{ml}$ of $2 \mathrm{M} \mathrm{LiCl}$ for $5 \mathrm{~min}$ at room temperature, mixed with $10 \mathrm{ml}$ of ScintiSafe liquid scintillation mixture (Thermo Fisher Scientific), and the radioactivity was counted in a liquid scintillation counter. Samples containing retinal homogenates heatinactivated before addition of the substrate were used as a negative control and did not produce detectable $\left[{ }^{3} \mathrm{H}\right] 5^{\prime} \mathrm{GMP}$.

retGC activity assay. The retGC activity in retinal homogenates was assayed under infrared illumination using $\left[\alpha-{ }^{32} \mathrm{P}\right] \mathrm{GTP}$ as a substrate and the product of the reaction was analyzed by thin-layer chromatography as previously described in detail (Olshevskaya et al., 2012). $\mathrm{Ca}^{2+} /$ EGTA buffers used for measuring $\mathrm{Ca}^{2+}$ sensitivity of retGC regulation were produced as described by the method of Tsien and Pozzan (Makino et al., 2008).

Protein kinase G activity assay. Protein kinase G (PKG) activity in the retinal lysate was assayed by colorimetric analysis using the CycLex cGMP-dependent Protein Kinase Assay Kit (MBL International). Briefly, $100 \mu \mathrm{g}$ (protein) of retinal lysates was diluted in the final volume of 200 $\mu \mathrm{l}$ of the kinase buffer. The samples were then placed in the microtiter assay plate and incubated for $30 \mathrm{~min}$ at $30^{\circ} \mathrm{C}$. After washing five times, $100 \mu \mathrm{l}$ of HRP-conjugated antibody was added to each well and incubated for $1 \mathrm{~h}$ at room temperature. Following the incubation, the wells were washed five times and then substrate reagent was added. The reaction was then stopped with stop solution, and the absorbance at $450 \mathrm{~nm}$ was measured with SpectraMax 190 Microplate Spectrophotometer (Molecular Devices). Each reaction was performed in duplicate and results are an average of three to four independent experiments using retinas prepared from five to eight mice.

Retinal protein sample preparation, SDS-PAGE, and Western blot anal$y$ sis. Retinal protein sample preparation, SDS-PAGE, and Western blotting were performed as described previously (Xu et al., 2011). Briefly, retinas were homogenized in homogenization buffer [20 mM HEPES$\mathrm{NaOH}, \mathrm{pH}$ 7.4, 1 mм EDTA, 200 mm sucrose, containing protease cocktail (Sigma)]. The homogenate was centrifuged at $1000 \times g$ for $10 \mathrm{~min}$ at $4^{\circ} \mathrm{C}$ to pellet down nuclei and cell debris. The supernatant of the homogenate was further centrifuged at $16,000 \times g$ for $30 \mathrm{~min}$ at $4^{\circ} \mathrm{C}$ to separate out cytosolic (supernatant) and membrane fractions (pellet). Protein concentration was measured using a Bio-Rad Protein Assay kit (Bio-Rad).

The protein samples were solubilized in SDS-PAGE sample buffer and separated on a $10 \%$ SDS-PAGE and transferred onto polyvinylidene difluoride membrane (Bio-Rad). After 1 h blocking in 5\% milk or $5 \%$ bovine serum albumin (BSA) containing Tris-buffered saline with $0.1 \%$ 
Tween $(\mathrm{v} / \mathrm{v}$; TBST) at room temperature, the membranes were incubated with primary antibodies overnight at $4^{\circ} \mathrm{C}$ (anti-retGC1, 1:2000; antiretGC2, 1:2000; anti-GCAP1, 1:2000; anti-GCAP2, 1:2000; anti-Mopsin, 1:2000; rabbit anti-S-opsin, 1:2000; anti-CAR, 1:2000; anti-Gnat2, 1:1500; anti-PDE6C, 1:500; anti-NCKX2, 1:1000; anti-PKG1, 1:500; and anti- $\beta$-actin, 1:2000). The membranes were then washed with TBST three to four times and incubated with HRP-conjugated secondary antirabbit or anti-mouse antibodies for $1 \mathrm{~h}$ at room temperature. After washing, the antigen and antibody binding was detected using SuperSignal West Dura Extended Duration chemiluminescent substrate (Pierce). The blots were scanned and images were captured using a KODAK Image Station 4000R Digital Imaging System (Carestream Molecular Imaging). Densitometry analysis was performed by quantifying the intensities of the bands of interest using Kodak Molecular Imaging software with $\beta$-actin as a loading control. Data for each group were obtained from three to four independent Western blot experiments performed using retinas prepared from four to five mice and analyzed and graphed using GraphPad Prism software (GraphPad Software).

Eye preparation, immunofluorescence labeling, and confocal microscopy. Mouse retinal cross sections or whole mounts were prepared for immunohistochemical analysis as described previously (Xu et al., 2011). For retinal sections, mouse eyes were enucleated (euthanasia of mice was performed by $\mathrm{CO}_{2}$ asphyxiation) and fixed in $4 \%$ formaldehyde (Polysciences) in $0.1 \mathrm{M}$ sodium phosphate buffer, $\mathrm{pH} 7.4$, for at $4^{\circ} \mathrm{C}$ for $16 \mathrm{~h}(30$ min for cryo preparation). The superior portion of the cornea was marked for orientation before enucleation. Fixed eyes were then stored in $70 \%$ ethanol until processing. Tissue sections passing vertically through the retina were prepared using a Leica microtome ( $5 \mu \mathrm{m}$ thickness) and Leica cryostat (for cryo sections, $10 \mu \mathrm{m}$ thickness), respectively. For whole-mount preparations, eyes were enucleated, marked at the superior pole with green dye, and fixed in 4\% formaldehyde for 5-10 min. The cornea and lens were removed, and the eyes were fixed in $4 \%$ formaldehyde at room temperature for $4-6 \mathrm{~h}$. The retina was then marked for orientation with a small cut left of the superior portion, and the retina was isolated.

Immunofluorescence labeling was performed as described previously (Ding et al., 2009). Briefly, retinal whole mounts or sections were blocked in PBS containing 5\% BSA and $0.5 \%$ Triton X-100 for $1 \mathrm{~h}$ at room temperature or $4^{\circ} \mathrm{C}$ overnight. When necessary, antigen retrieval was performed by incubating tissues in $10 \mathrm{~mm}$ sodium citrate buffer, $\mathrm{pH}$ 6.0, for $30 \mathrm{~min}$ in a $65^{\circ} \mathrm{C}$ water bath. Primary antibody incubation (anti-Mopsin, 1:500; anti-S-opsin, 1:500; anti-cGMP, 1:50; and anti-PKGI, 1:100) was performed at room temperature for $2 \mathrm{~h}$. Following Alexa- or FITC-conjugated secondary antibody incubation and rinses, slides were mounted and coverslipped. Peanut agglutinin (PNA) immunohistochemistry was performed using biotinylated PNA (Vector Laboratories; 1:50) and streptavidin-FITC (Sigma-Aldrich; 1:200). Fluorescent signals were imaged using an Olympus AX70 fluorescence microscope (Olympus) with QCapture imaging software (QImaging), or an Olympus IX81FV500 confocal laser scanning microscope (Olympus; using excitation wavelengths of $543 \mathrm{~nm}$ for Alexa and $488 \mathrm{~nm}$ for FITC) and FluoView imaging software (Olympus).

Evaluations of cone density on retinal sections and retinal whole mounts were performed as described previously (Xu et al., 2011). For sections, images were taken using a $40 \times$ objective on an Olympus microscope at four locations of the superior and inferior retinal sections. The four locations are $\sim 33$ and $67 \%$ of the distance between the superior pole and the optic nerve and $\sim 33$ and $67 \%$ of the distance between the inferior pole and the optic nerve. For whole mounts, images were taken (using a $40 \times$ objective on an Olympus microscope) $\sim 1.0 \mathrm{~mm}$ from the optic nerve in the center of each quadrant of the whole mounts. Image scale was calibrated and cones were counted within the rectangles $(336 \times$ $256 \mu \mathrm{m})$ (sections) or squares $(125 \times 125 \mu \mathrm{m})$ (whole mounts) using Image Pro 6 software (Media Cybernetics). The averages of the counts were analyzed and graphed using GraphPad Prism software (GraphPad Software).

RNA isolation and quantitative real-time PCR. Total RNA was isolated from mouse retinas using Trizol reagent (Invitrogen). Two micrograms of total RNA was reverse-transcribed using an oligo-dT primer and $\mathrm{Su}-$
perScript III reverse transcriptase (Invitrogen) as per the manufacturer's instructions. Control assays without addition of transcriptase were included and the products were used in the subsequent quantitative realtime (qRT)-PCR as negative controls.

qRT-PCR was performed to detect mRNA levels of retGC1, retGC2, and the internal control gene hypoxanthine guanine phosphoribosyl transferase 1 (Hprt-1). Primers used for retGC1 were as follows: (forward) 5' -TCAAGGTGACAGATCATGGC, (reverse) 5' -GACATCACCA GCTAGAGTTCC. Primers for retGC2 were as follows: (forward) $5^{\prime}$-CA GAACAGCGACCAACTTTTG, (reverse) 5'-TCCCGGATCAAATCTT CCAAG. Primers for HPRT-1 were as follows: (forward) 5' -GCAAACTT TGCTTTCCCTGGTT, (reverse) 5'-CAAGGGCATATCCAACAACA. The assays were performed on each cDNA sample using a real-time PCR detection system (iCycler; Bio-Rad). A relative gene expression value was calculated based on the $\Delta \Delta \mathrm{cT}$ method using Hprt-1 gene as internal control (Ding et al., 2009). Disassociation curve analysis and agarose gel electrophoresis were performed on all PCR products to confirm the proper amplification. The assays were repeated with at least three different animals for each genotype.

Statistical analysis. Unpaired or paired Student's $t$ tests and one-way ANOVA (Newman-Keuls) were used to statistically evaluate the significances of differences between two groups and among several groups, respectively. Statistical analyses were performed using KaleidaGraph (Synergy Software Systems) or GraphPad Prism version 5.01 for Windows (GraphPad Software).

\section{Results}

\section{Time course of cGMP accumulation in $\mathrm{Cnga3}^{-/-} ; \mathrm{Nrl}^{-/-}$} retinas

We recently showed that cGMP levels rise in $\mathrm{Cnga3}^{-1-}$ and $\mathrm{Cnga3}^{-1-} ; \mathrm{Nrl}^{-1-}$ mouse retinas by P30 (Michalakis et al., 2010; Thapa et al., 2012). Here, we examined the time course of cGMP elevation in $\mathrm{Cnga3}^{-1-} ; \mathrm{Nrl}^{-1-}$ retinas and found that the cGMP level sharply increased at P8, peaked at postnatal day 10-15 (P10-P15), stayed high through P30-P60, and returned to near control level at P90 (Fig. 1A). There was no difference in retinal cGMP levels between $\mathrm{Cnga3}^{-1-} ; \mathrm{Nrl}^{-1-}$ and $\mathrm{Nrl}^{-1-}$ mice at P6; however, it increased sharply, nearly 30-fold, in $\mathrm{Cnga3}^{-1-}$; $\mathrm{Nrl}^{-1-}$ mice at P8, compared with age-matched $\mathrm{Nrl}^{-1-}$ controls, and remained drastically elevated nearly 65-, 80-, 25-, and 8-fold at $\mathrm{P} 10, \mathrm{P} 15, \mathrm{P} 30$, and $\mathrm{P} 60$, respectively (Fig. 1A). The cGMP accumulation in CNG channel-deficient mice coincided with cone apoptotic death, which typically peaked around P15-P20 (Michalakis et al., 2005; Thapa et al., 2012). It needs to be noted that the $\mathrm{Nrl}^{-1-}$ cones undergo partial degeneration starting $\sim 2$ months of age (Mears et al., 2001; Daniele et al., 2005). The accumulation and the beginning of the decline in total cGMP levels in $\mathrm{Cnga3}^{-1-} ; \mathrm{Nrl}^{-1-}$ mice aged 30 d preceded the degeneration. Moreover, age-matched $\mathrm{Nrl}^{-1-}$ mice have been used for all age groups, which argues that the observed accumulation of cGMP in the $\mathrm{Cnga3}^{-1-} ; \mathrm{Nrl}^{-1-}$ retina is unlikely caused by the slow degeneration associated with the NRL deficiency. The accumulation of cGMP in $\mathrm{Cnga3}^{-1-} ; \mathrm{Nrl}^{-1-}$ retina was also evident when tested by anti-cGMP immunofluorescence. A strong anticGMP immunoreactivity was detected in retinal sections of $\mathrm{Cnga3}^{-1-} ; \mathrm{Nrl}^{-1-}$ but not $\mathrm{Nrl}^{-1-}$ mice at P15 and P30 (Fig. $1 \mathrm{~B}$ ). As cAMP has been shown to be abnormally elevated in several retinal degeneration models, including $r d 1 / r d 1$ and certain rhodopsin mutants (Lolley et al., 1974; Weiss et al., 1995), we examined cAMP levels in $\mathrm{Cnga3}^{-1-} ; \mathrm{Nrl}^{-1-}$ and $\mathrm{Nrl}^{-1-}$ retinas, and found no difference between the two groups (Fig. 1C). Hence only cGMP was accumulated in the CNG channel-deficient retina. 


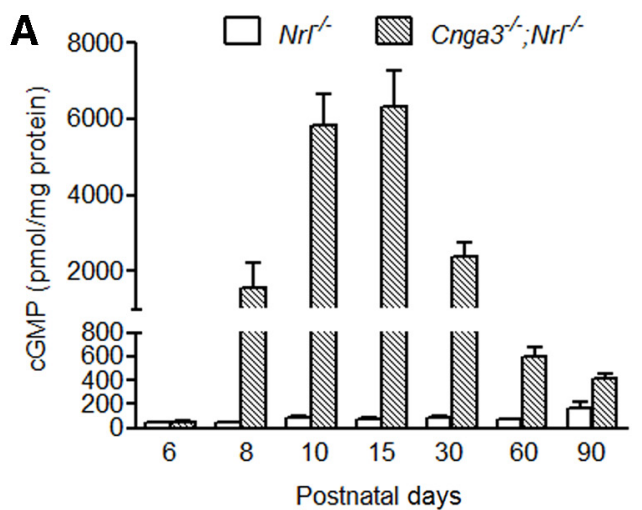

B
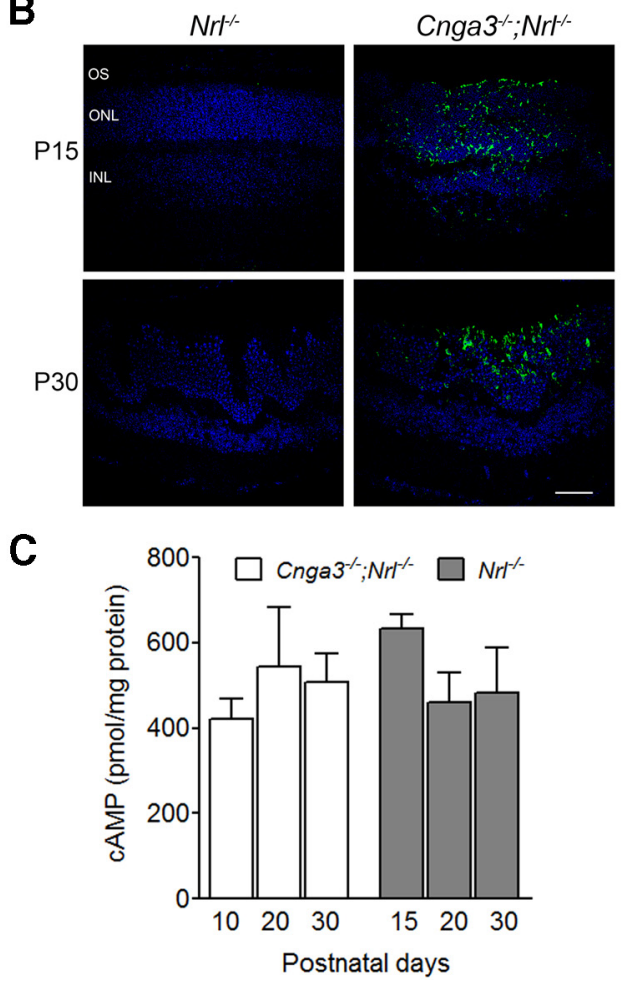

Figure 1. Time course of CGMP accumulation in $\mathrm{Cnga}^{-1-} ; \mathrm{Nr}^{-/-}$retina. $\mathrm{A}$, ELISA analysis of retinal $\mathrm{CGMPlevel}$ in $\mathrm{Cnga}^{-1-} ; \mathrm{Nrl}^{-/-}$and $\mathrm{Nrl}^{-1-}$ mice at varying ages from P6 to P90. B, Confocal images of immunofluorescence labeling of $\mathrm{GMP}$ in retinal sections from $\mathrm{Cnga}^{-1-}$; $\mathrm{Nrl}^{-1-}$ and $\mathrm{Nrl}^{-1-}$ mice at P15 and P30. OS, outer segment; ONL, outer nuclear layer; INL, inner nuclear layer. Scale bar, $50 \mu \mathrm{m}$. C, ELISA analysis of retinal cAMP levels in $\mathrm{Cnga}^{-1-}$; $\mathrm{Nrl}^{-1-}$ and $\mathrm{Nrl}^{-1-}$ mice at P10, P20, and P30. Data are represented as mean \pm SEM three to four measurements using retinas from six to eight mice.

\section{PDE6C enzyme activity is not reduced in $\mathrm{Cnga3}^{-/-} ; \mathrm{Nrl}^{-/-}$} mice

The PDE6 activity and expression level of PDE6C (the $\alpha^{\prime}$-subunit of cone PDE6) were examined in $\mathrm{Cnga3}^{-/-} ; \mathrm{Nrl}^{-1-}$ mice to determine whether the elevation of cGMP could be caused by PDE6 inhibition. The enzyme activity assays showed that PDE6 activity in the illuminated $\mathrm{Cnga3}^{-1-} ; \mathrm{Nrl}^{-I-}$ retinas (extracted at P15) was not significantly different from that in the $\mathrm{Nrl}^{-1-}$ retinas $(p=0.90$; Fig. $2 A)$. The average levels of PDE6 activity appeared equal in $\mathrm{Cnga3}^{-1-} ; \mathrm{Nrl}^{-1-}$ and the control $\mathrm{Nrl}^{-1-}$ group. Even though the activity varied between different retinal samples, any possible difference between these two lines could not possibly account for the striking rise in cGMP accumulation in $\mathrm{Cnga3}^{-/-}$; $\mathrm{Nrl}^{-1-}$. Interestingly, Western blot analysis showed $\sim 30 \%$ increase in PDE6C expression level in $\mathrm{Cnga3}^{-1-} ; \mathrm{Nrl}^{-1-}$ retinas,
A

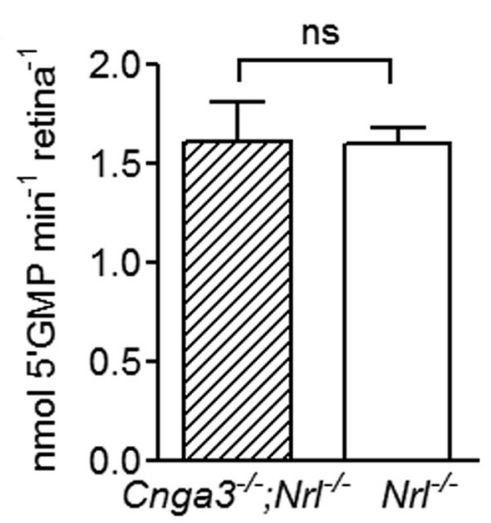

B
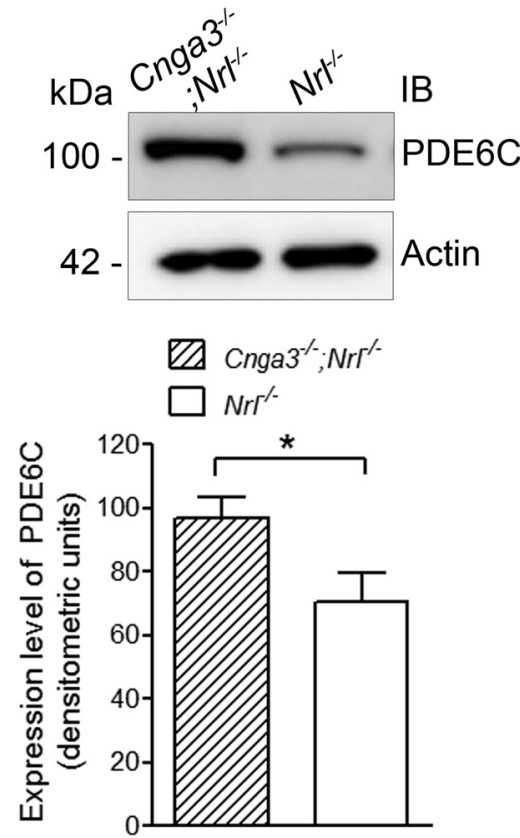

C

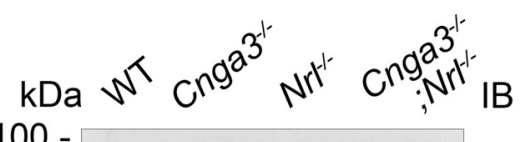

100

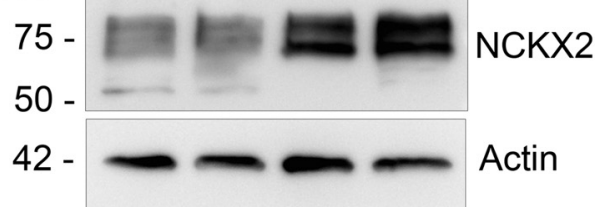

Figure 2. PDE6 enzyme activity is not reduced in $\mathrm{Cnga}^{-1-} ; \mathrm{Nrl}^{-1-}$ retina. A, PDE activity measured in retinal preparations from $\mathrm{Cnga3}^{-1-} ; \mathrm{Nrl}^{-1-}$ and $\mathrm{Nrl}^{-1-}$ mice at P15. Data are represented as mean \pm SEM four assays. Each assay was performed using four retinas (prepared from 2 to 4 mice). Unpaired Student's $t$ test was used to evaluate the significances of differences between Cnga ${ }^{-I-} ; \mathrm{Nrl}^{-1-}$ and $\mathrm{Nrl}^{-/-}$mice. B, Western immunoblotting (IB) detection of PDE6C expression in $\mathrm{Cnga}^{-1-} ; \mathrm{Nrl}^{-1-}$ and $\mathrm{Nrl}^{-1-}$ retinas at P30. Shown are representative images of the Western blots (top) and the densitometric quantification (bottom). Data are represented as mean \pm SEM three assays using retinas from five to eight mice. Unpaired Student's t test was used to evaluate the significances of differences between $\mathrm{Cnga3}^{-1-} ; \mathrm{Nrl}^{-1-}$ and $\mathrm{Nrl}^{-1-}$ mice $\left.{ }^{*} p<0.05\right)$. C, Expression of NCKX2 in $\mathrm{Cnga3}^{-1-} ; \mathrm{Nrl}^{-1-}$ and $\mathrm{Nrl}^{-1-}$ retinas at P30. Shown are representative images of the Western blot detections. WT, wild-type.

compared with the $\mathrm{Nrl}^{-1-}$ controls $(p=0.03$; Fig. $2 B$ ). Thus, the elevation of cGMP in CNG channel-deficient mice is unlikely to be caused by inhibition of cone PDE6. On the contrary-if anything, the enzyme could be slightly upregulated, based on the 
A

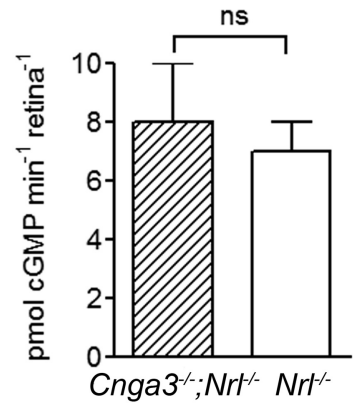

C
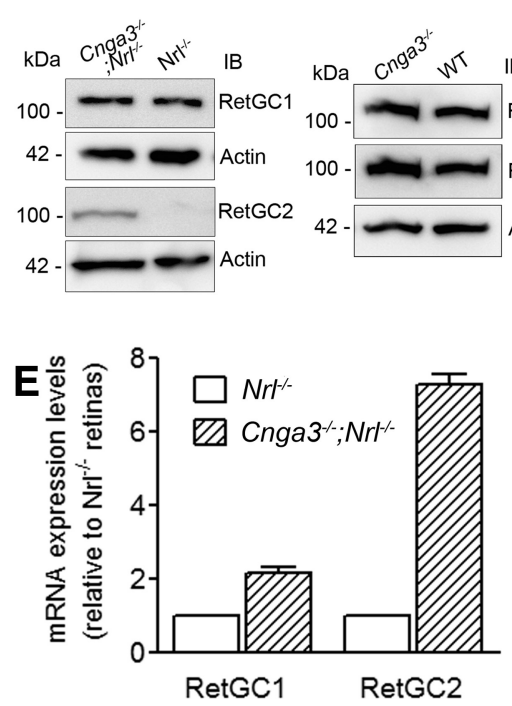

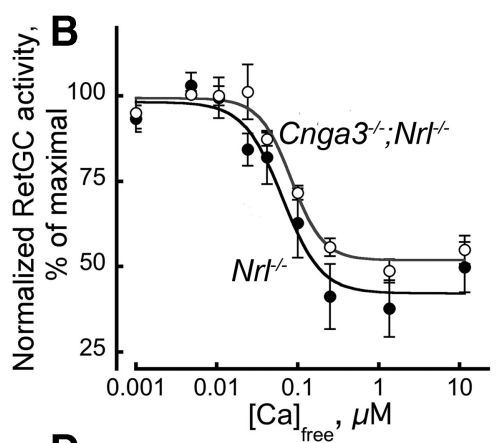

D

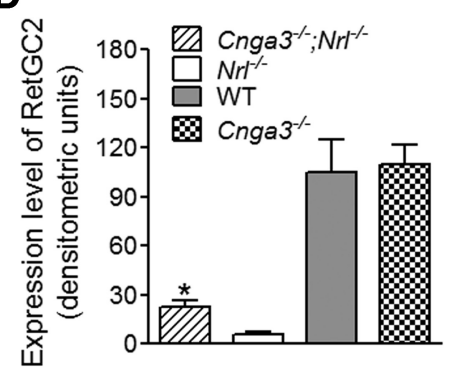

$\mathbf{F}$

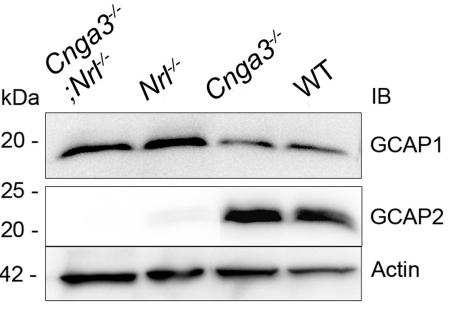

Figure 3. GC enzyme activity is not increased in $\mathrm{Cnga}^{-1-} ; \mathrm{Nrl}{ }^{-1-}$ retina. $\boldsymbol{A}, \boldsymbol{B}$, Total GC activity $(\boldsymbol{A})$ and $\mathrm{GC}$ sensitivity to $\mathrm{Ca}^{2+}$ $(\boldsymbol{B})$ were measured using retinal preparations from $\mathrm{Cnga3}^{-1-} ; \mathrm{Nrl}^{-1-}$ and $\mathrm{Nrl}^{-1-}$ mice at P15 by chromatographic analyses. Data are represented as mean \pm SEM four assays. Each assay was performed using four retinas (prepared from 2 to 4 mice). Unpaired Student's $t$ test (for total GC activity) and one-way ANOVA (Newman-Keuls) using KaleidaGraph (for Ca ${ }^{2+}$ sensitivity of the enzyme) were used to evaluate the significances of differences between $\left(n g a 3^{-1-} ; \mathrm{Nrl}^{-1-}\right.$ and $\mathrm{Nr}^{-1-}$ mice. C, D, Western blot detection of retGC1 and retGC2 expression in $\mathrm{Cnga}^{-1-} ; \mathrm{Nrl}^{-1-}, \mathrm{Nrl}^{-1-}, \mathrm{Cnga}^{-1-}$, and wild-type (WT) mice at P30. Shown are representative images of the Western immunoblotting $(I B ; C)$ and the densitometric quantification of retGC2 expression (D). $\boldsymbol{E}$, qRT-PCR analysis of retGC1 and retGC2 mRNA levels in $\mathrm{Cnga}^{-1-} ; \mathrm{Nrl}^{-1-}$ and $\mathrm{Nrl}^{-1-}$ mice at P30. Data are represented as mean \pm SEM three to four assays using retinas from five to eight mice. Unpaired Student's $t$ test was used to evaluate the significances of differences in retGC2 protein expression levels between $\mathrm{Cnga}^{-1-} ; \mathrm{Nrl}^{-1-}$ and $\mathrm{Nrl}^{-1-}$ mice $\left({ }^{*} \mathrm{p}<0.05\right) . \boldsymbol{F}$, Western blot detection of GCAP1 and GCAP2 expression in $\mathrm{Cnga3}^{-1-} ; \mathrm{Nrl}^{-1-}$ and $\mathrm{Nrl}^{-1-}$ mice at P30. Shown are representative images of the Western blot detections.

immunoblotting detection. For a reason that is not immediately apparent, the upregulation of the enzyme does not produce the corresponding increase of the total cGMP hydrolysis in their retinal homogenates. However, we cannot exclude that variability of the measurements between different retinas could mask a slight increase in PDE activity. Yet, even if that were the case, such a change would be expected to slightly decrease the overall cGMP content. We also examined the expression of the cone $\mathrm{Na}^{+} /$ $\mathrm{Ca}^{2+}-\mathrm{K}^{+}$exchanger NCKX2, which is abundantly expressed in $\mathrm{Nrl}^{-1-}$ retinas (Matveev et al., 2008), and detected no change in its expression level between the $\mathrm{Cnga3}^{-1-} ; \mathrm{Nrl}^{-/-}$and $\mathrm{Nrl}^{-/-}$ control group (Fig. 2C).

\section{GC enzyme activity is not increased in $\mathrm{Cnga3}^{-/-} ; \mathrm{Nrl}^{-/-}$ retina}

We next examined activity and expression levels of retGC in $\mathrm{Cnga3}^{-1-} ; \mathrm{Nrl}^{-1-}$ mice to explore whether the increased cGMP level in CNG channel-deficient mice results from increased synthesis. The in vitro retGC activity assays were performed using retinas isolated from mice at $\mathrm{P} 15$ as the retinal cGMP levels peaked around that age. Figure $3, A$ and $B$, shows the total retGC activity (Fig. $3 A$ ) and the sensitivity to $\mathrm{Ca}^{2+}$ of the enzyme (Fig. 3B). Levels of the retGC activity in the two groups were almost indistinguishable. There was a small shift in the $\mathrm{Ca}^{2+}$ sensitivity for the $\mathrm{Cnga3}^{-1-} ; \mathrm{Nrl}^{-1-}$ retinas toward becoming slightly less sensitive to $\mathrm{Ca}^{2+}$ than the $\mathrm{Nrl}^{-1-}$ (Fig. 3B). However, one-way ANOVA (Newman-Keuls, using KaleidaGraph) failed to detect any statistically significant differences in the sensitivity to $\mathrm{Ca}^{2+}$ of the enzyme between $\mathrm{Cnga3}^{-1-}$; $\mathrm{Nrl}^{-1-}$ and $\mathrm{Nrl}^{-1-}$ mice $(p>0.05)$. The variability between individual retinal samples would not allow us to exclude with confidence that the $\mathrm{Ca}^{2+}$ sensitivity was not identical, but the slight change in the $\mathrm{EC}_{50}$, if any, could possibly account for the dramatic change in cGMP levels in $\mathrm{Cnga}^{-1-} ; \mathrm{Nrl}^{-1-}$ retinas. A slight shift in $\mathrm{Ca}^{2+}$ sensitivity of the cyclase regulation does not affect mouse rods expressing bovine ortholog of GCAP1 (Olshevskaya et al., 2004).

There are two isoforms of retGCs in the mammalian retina, retGC1 and retGC2 (Dizhoor et al., 1994; Lowe et al., 1995). Both isoforms were present in $\mathrm{Cnga3}^{-1-} ; \mathrm{Nrl}^{-1-}$ retina. Figure 3C shows representative images of immunoblots of P30 $\mathrm{Cnga3}^{-1-} ; \mathrm{Nrl}^{-1-}, \mathrm{Nrl}^{-1-}$, $\mathrm{Cnga}^{-1-}$, and wild-type retina lysates probed with retGC1 and retGC2 antibodies. RetGC1 was detected at similar levels in both rod-dominant (wild-type and $\left.\mathrm{Cnga3}^{-l-}\right)$ and cone-dominant $\left(\mathrm{Nrl}^{-1-}\right.$ and $\mathrm{Cnga3}^{-1-} ; \mathrm{Nrl}^{-1-}$ ) retinas, whereas retGC2 was more abundantly detected in the rod-dominant retinas. By densitometry, retGC2 expression level in wild-type and $\mathrm{Cnga}^{-1-}$ mice was $\sim 10$-fold higher than in $\mathrm{Nrl}^{-1-}$ mice, whereas retGC2 expression level in $\mathrm{Cnga3}^{-1-}$; $\mathrm{Nrl}^{-1-}$ mice was $\sim 4$-fold higher than in $\mathrm{Nrl}^{-1-}$ mice (Fig. 3D). The expression of retGC1 and retGC2 was also examined at mRNA level by qRT-PCR. These analyses showed that retGC2 mRNA level was increased nearly sixfold in $\mathrm{Cnga3}^{-1-} ; \mathrm{Nrl}^{-1-}$ mice, compared with the $\mathrm{Nrl}^{-1-}$ controls (Fig. 3E). Hence there was an upregulation of retGC2 expression in the channeldeficient retina. However, as the maximal retinal GC activity was unchanged (Fig. 3A), we presume that most of the cGMP synthetic capacity in $\mathrm{Cnga3}^{-1-} ; \mathrm{Nrl}^{-/-}$cones likely originated from retGC1. The following may explain why we did not detect a parallel increase in the GC activity. RetGCl is the most abundant isozyme in mouse retinas (Olshevskaya et al., 2012) and is barely detectable in $\mathrm{Nrl}^{-1-}$ retinas. Therefore, despite the increase in retGC2 levels in $\mathrm{Cnga}^{-1-} ; \mathrm{Nrl}^{-1-}$, the absolute increase in retGC2 may not be significant enough to cause an increase in the overall retGC activity. In any case, our data argue that the accumulation of cGMP in CNG channel-deficient mice is unlikely to 
be caused by the increase in the retGC activity or change in its regulation.

We further examined expression levels of GCAP1 and GCAP2 in the channel-deficient retinas. Similar to the expression patterns of retinal retGCs, GCAP1 was detected in both rod- and cone-dominant retinas, and GCAP2 was more abundant in the rod-dominant retinas but poorly detectable in $\mathrm{Nrl}^{-/-}$and $\mathrm{Cnga3}^{-1-} ; \mathrm{Nrl}^{-1-}$ retinas. Expression levels of GCAP1 and GCAP2 were not different between channel-deficient retinas $\left(\mathrm{Cnga3}^{-1-} ; \mathrm{Nrl}^{-1-}\right.$ and $\left.\mathrm{Cnga3}^{-1-}\right)$ and their respective controls $\left(\mathrm{Nrl}^{-1-}\right.$ and wild-type; Fig. $\left.3 \mathrm{~F}\right)$.

\section{Cone survival was improved in $\mathrm{Cnga3}^{-/-} ; \mathrm{Gucy}^{2} \mathrm{e}^{-/-}$mice}

To determine the contribution of cGMP accumulation to cone death, we examined cone survival in $\mathrm{Cnga3}^{-1-}$ mice lacking retGC1 (Gucy2e deletion; Yang et al., 1999). The double knockout $\mathrm{Cnga3}^{-1-} ; \mathrm{Gucy}_{2} e^{-/-}$mouse line was generated by crossmating and used to determine whether cone degeneration in $\mathrm{Cnga3}^{-1-} ; \mathrm{Gucy} 2 \mathrm{e}^{-1-}$ mice can be reduced or slowed down when compared with $\mathrm{Cnga}^{-1-}$ mice. The rationale for deleting Gucy2 $e^{-1-}$ in CNG channel-deficient mice was based on the findings that (1) retGC1 is more robustly expressed in cones (relative to expression of retGC2) (Dizhoor et al., 1994; Fig. 3C,D), (2) retGC1 (but not retGC2) is critical for cone function and survival (Yang et al., 1999; Baehr et al., 2007), and (3) cone degeneration in Gucy2e $e^{-1-}$ mice is relatively slow and late onset (Yang et al., 1999) when compared with $\mathrm{Cnga3}^{-1-}$ mice. Cone degeneration in $\mathrm{Cnga3}^{-1-}$ mice was evident from the second postnatal week on, and it proceeded fast (particularly in the inferior region of the retina; Michalakis et al., 2005). In contrast, Gucy $2 e^{-1-}$ mice display a slowly progressing cone dystrophy, and the number of cones appeared normal throughout the superior and inferior retinal regions in 4- and 5-week-old Gucy2e $e^{-I-}$ mice, although gradually decreased by 6 months (Coleman et al., 2004). Indeed, cone density measurement at 1 and 3 months, confirmed that $\mathrm{Cnga3}^{-1-}$ cones degenerate more severely than in the age-matched Gucy $2 e^{-1-}$ mice (Fig. 4A).

We next evaluated cone survival in $\mathrm{Cnga3}^{-1-} ; \mathrm{Gucy} 2 e^{-1-}$ mice at 1,3,6, and 9 months by immunohistochemistry. Cone density analysis in $\mathrm{Cnga3}^{-1-} ;$ Gucy $2 e^{-/-}$retinal whole-mount preparations and retinal cross sections using cone-specific markers revealed a significantly better cone survival, compared with the age-matched $\mathrm{Cnga3}^{-/-}$mice. Figure $4 B$ shows results of cone density analyzed by $\mathrm{M}$-opsin labeling on retinal whole mounts prepared from $\mathrm{Cnga3}^{-1-} ; \mathrm{Gucy}_{2 e^{-1-}}, \mathrm{Cnga3}^{-1-}$ and wild-type mice at 6 months. Cone density in $C n g a 3^{-1-}$ mice was significantly reduced in all four quadrants (superior, inferior, nasal, and temporal), compared with the wild-type, with the density in the inferior retina being reduced most strongly, which was consistent with previous reports (Michalakis et al., 2005). However, a much better preservation of cones was detected in $\mathrm{Cnga}^{-1-}$; Gucy $2 e^{-1-}$ double knock-out mice. M-opsin labeling at the superior, inferior, nasal, and temporal quadrants of $\mathrm{Cnga3}^{-1-}$; Gucy $2 e^{-1-}$ retina was increased by $\sim 140,130,90$, and $140 \%$, respectively, compared with the age-matched $\mathrm{Cnga3}^{-1-}$ mice (Fig. $4 B$, bottom). All four retinal quadrants in $\mathrm{Cnga3}^{-1-}$; Gucy $2 e^{-1-}$ showed improvement of the cone count-from nearly $30 \%$ at the wild-type level in the inferior portion to nearly $60 \%$ in other parts of the retina (Fig. $4 B$ ). The increased cone density in $\mathrm{Cnga3}^{-l-} ; \mathrm{Gucy}_{2 e^{-l-}}$ mice was also shown by S-opsin labeling (Fig. 4C). The improved cone survival in $\mathrm{Cnga3}^{-1-}$; Gucy2 $2 e^{-1-}$ mice was observed as early as 1 month and remained evident at 9 months (the oldest age examined, data not shown). However, it needs to be emphasized that the rescue was never complete and the

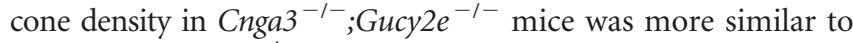
that of the Gucy2e $e^{-I-}$ retinas than to the wild-type.

The improved cone survival in Cnga3 ${ }^{-1-} ; \mathrm{Gucy}_{2 e^{-I-}}$ mice compared with the age-matched $\mathrm{Cnga3}^{-1-}$ was also evident from the increased expression of cone-specific proteins, including M-opsin, S-opsin, Gnat2, and CAR. At 3 months of age, expression levels of these proteins were increased by nearly 27,25 , 26, and 58\%, respectively (Fig. 5).

\section{Increased PKG activity and expression in $\mathrm{Cnga3}^{-1-} ; \mathrm{Nrl}^{-1-}$ retinas}

The cGMP-dependent PKG is one of the major cellular targets for cGMP. Therefore, to explore the potential downstream signaling, we compared expression levels and activity of PKG in $\mathrm{Cnga3}^{-1-}$; $\mathrm{Nrl}^{-1-}$ and $\mathrm{Nrl}^{-1-}$ retinas at P20 and P30. The assays showed that PKG activity in $\mathrm{Cnga3}^{-/-} ; \mathrm{Nrl}^{-1-}$ retinas at P20 and P30 was increased by $\sim 85$ and $89 \%$, respectively, compared with their age-matched $\mathrm{Nrl}^{-1-}$ controls (unpaired Student's $t$ test, $p$ values of 0.0054 and 0.0050 , respectively; Fig. $6 A$ ). PKG has two isozymes: PKGI, which predominantly localizes to the cytoplasm and is involved in functional regulation of neurons, and PKGII, which is mainly anchored to the plasma membrane by N-terminal myristoylation (Hofmann et al., 2006). PKGI was reported to have a potential regulatory role in photoreceptors (Gamm et al., 2000). Hence, we examined expression levels of PKGI in $\mathrm{Cnga3}^{-1-} ; \mathrm{Nrl}^{-1-}$ retinas (Fig. $6 \mathrm{~B}-\mathrm{C}$ ). Both immunofluorescence labeling (Fig. 6B) and immunoblotting (Fig. 6C) indicate that the levels of PKGI in $\mathrm{Cnga3}^{-1-} ; \mathrm{Nrl}^{-1-}$ retinas become increased. Densitometry analysis indicates that the PKGI expression level in $\mathrm{Cnga3}^{-1-} ; \mathrm{Nrl}^{-1-}$ mice was elevated by $24 \%$, compared with $\mathrm{Nrl}^{-1-}$ controls (unpaired Student's $t$ test, $p$ value of 0.0350 ; Fig. $6 C$, bottom).

\section{Discussion}

This work investigated the role of cGMP accumulation in cone degeneration in CNG channel deficiency animal models. The time course of cGMP accumulation was examined using $\mathrm{Cnga3}^{-1}$ $-; \mathrm{Nrl}^{-1-}$ mice that provide us several advantages in analyzing expression levels and activities of cone-specific proteins/components compared with wild-type and other mutants. We found that cGMP accumulation peaks at P10-P15, concomitant with the previously documented cone apoptotic death in both rodand cone-dominant mouse retinas, as the number of TUNELpositive photoreceptor nuclei increased after P12 and reached a maximum around P20 in $\mathrm{Cnga3}^{-1-}$ (Michalakis et al., 2005) and at P15-P20 in $\mathrm{Cnga3}^{-/-} ; \mathrm{Nrl}^{-1-}$ retinas (Thapa et al., 2012). This suggests an involvement of cGMP accumulation in triggering cone death in CNG channel deficiency. To further determine whether cGMP accumulation plays a role for cone death in CNG channel deficiency, we deleted retGC1, the predominant isozyme that synthesizes cGMP in mouse retina (Olshevskaya et al., 2012). We show that cone survival was significantly improved in Cnga3 ${ }^{-1-}$; Gucy $2 e^{-1-}$ retinas compared with Cnga $^{-1-}$ mice, thus revealing cGMP as a trigger or accelerator of cone death.

A number of mutations causing blindness by accelerating photoreceptor death has been linked to the abnormalities in production or decay of cGMP in rods and cones. The pathological elevation of cGMP and its cytotoxicity in the photoreceptor has been long recognized in $r d 1 / r d 1$ mice. The death of rods in $r d 1 /$ $r d 1$ mice is generally thought to associate with a persistent opening of CNG channels and a subsequent rise of cellular $\mathrm{Ca}^{2+}$ level (Paquet-Durand et al., 2011). A similar pathological mechanism also occurs in the transgenic Y99C-GCAP1 and E155G-GCAP1 
A
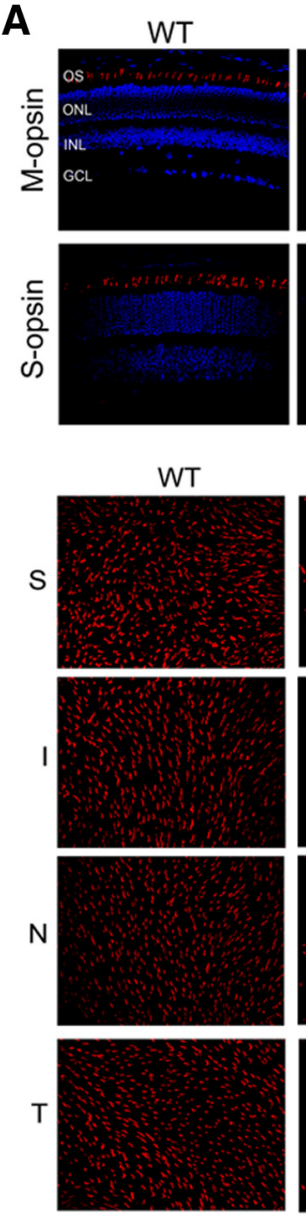

C
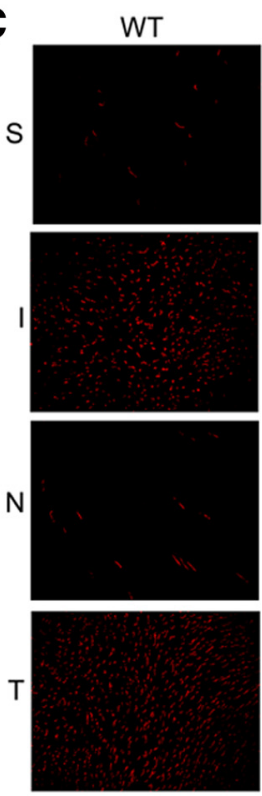

Cnga3
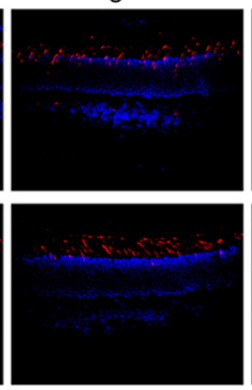

Cnga3
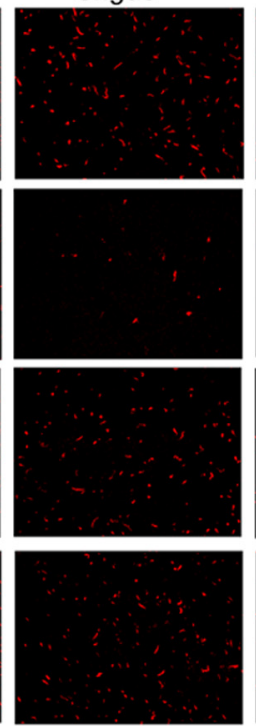

Cnga3 ${ }^{-1}$
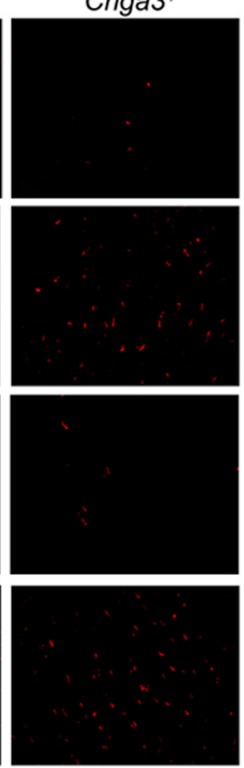

Gucy $2 e^{-\%}$

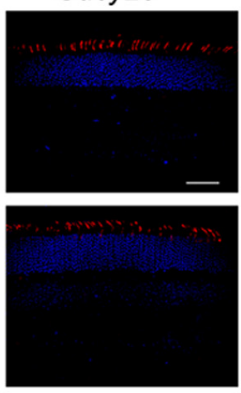

Gucy $2 e^{-/}$
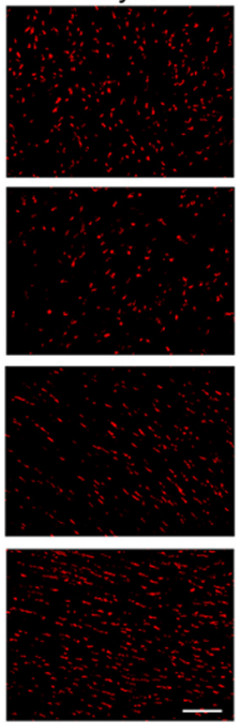

Cnga3 $\%$ Gucy $2 e^{-/}$
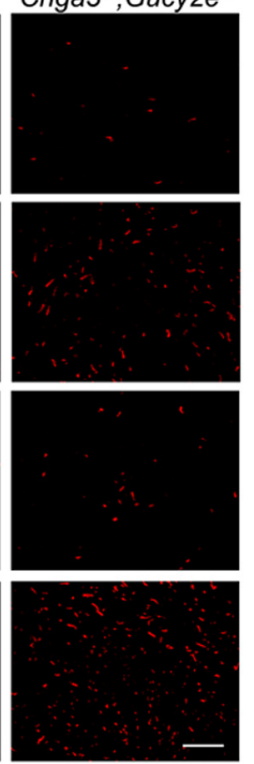

B
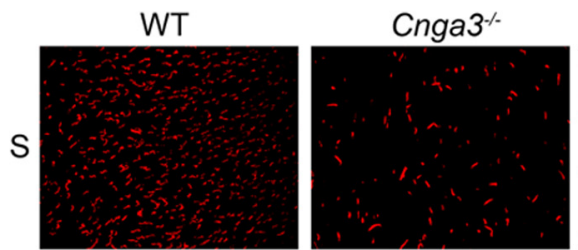

Cnga3 $\%$ Gucy $2 e^{\%}$
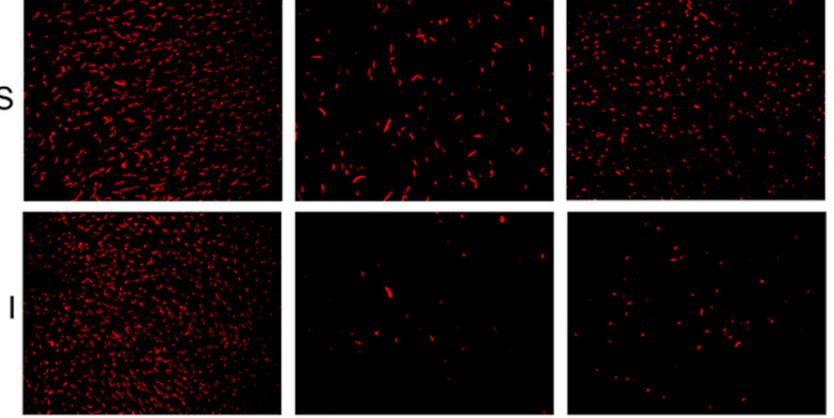

N
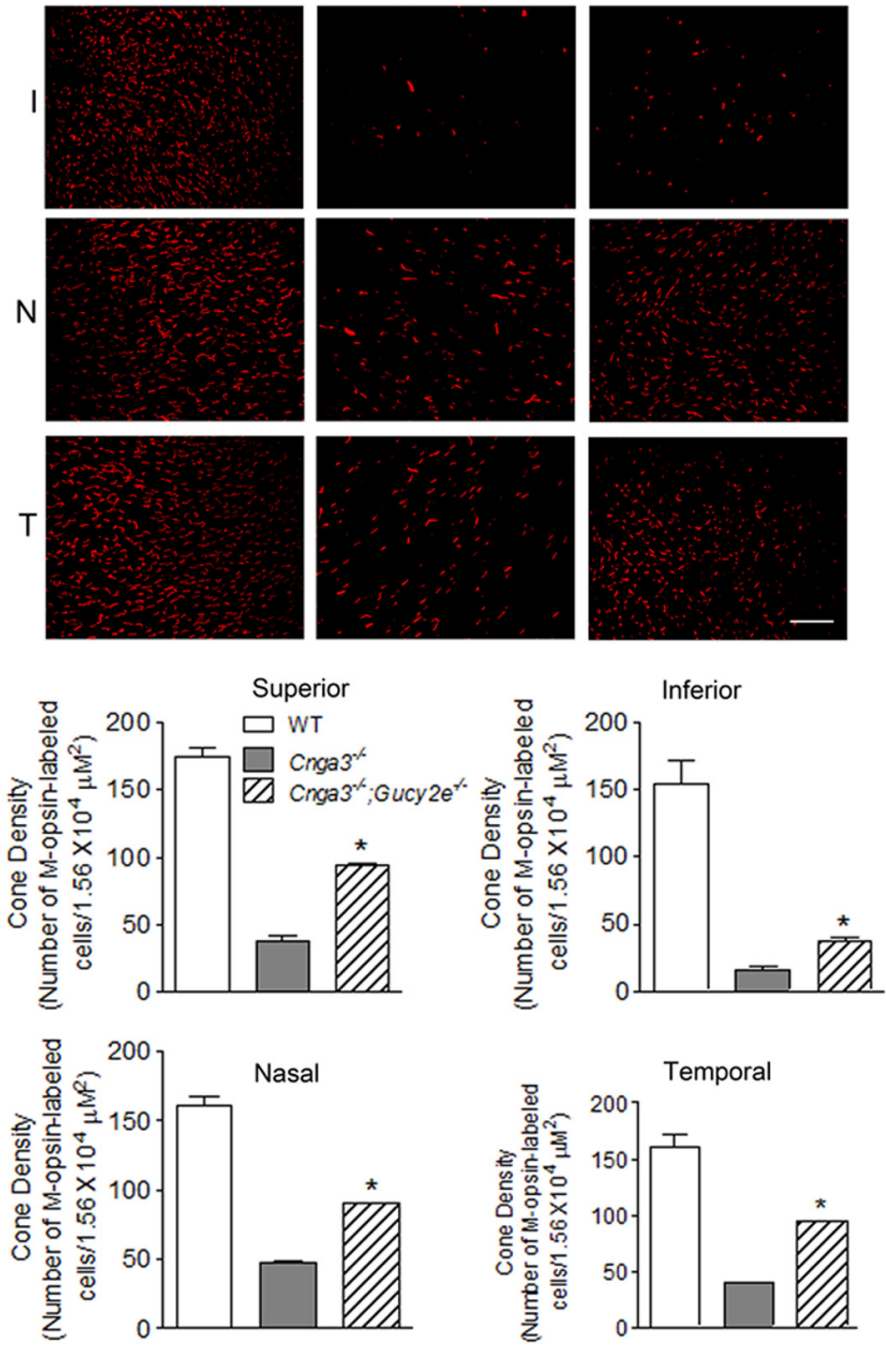

Figure 4. Increased cone density in Cnga $3^{-1-} ; G u c y 2 e^{-1-}$ compared with Cnga $3^{-1-}$ retinas. $A$, Shown are representative confocal images of immunofluorescence labeling of M- and S-opsin in retinal sections prepared from wild-type (WT), Cnga $3^{-1-}$, and Gucy2 $e^{-1-}$ mice at 1 month (top) and M-opsin labeling in retinal whole-mount preparations at 3 months of age (bottom). 0 , outer segment; ONL, outer nuclear layer; INL, inner nuclear layer; GCL, ganglion cell layer; S, superior; I, inferior; N, nasal; T, temporal. Scale bars: $50 \mu m$ (retinal sections); $10 \mu m$ (retinal whole

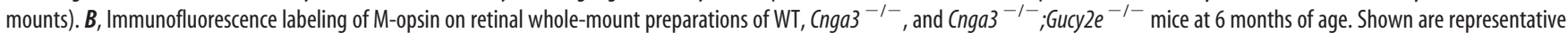
confocal images of immunolabeling in the four quadrants of the retinal whole mounts (top) and the quantitative analysis (bottom). Data are represented as mean \pm SEM measurements obtained

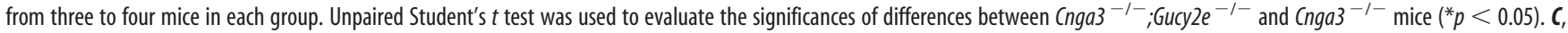
Immunofluorescence labeling of S-opsin on retinal whole-mount preparations of WT, Cnga $3^{-1-}$, and $\mathrm{Cnga3}^{-1-}$;Gucy2e ${ }^{-1-}$ mice at 6 months of age. 
mutants (Olshevskaya et al., 2004; Woodruff et al., 2007). These disease-causing mutations prevent complete inhibition of retGC1 in the dark, which leads to elevated production of cGMP, excessive opening of CNG channel, and increased cellular $\mathrm{Ca}^{2+}$ level in photoreceptors (Olshevskaya et al., 2004; Woodruff et al., 2007). Strategies to reduce cellular cGMP level by constitutive activation of rhodopsin with Rho(Gly90Asp) (Woodruff et al., 2007), by elimination of the target isozyme for the mutant GCAP1 in vivo (Olshevskaya et al., 2012), or by RNA interference knockdown of mutant GCAP1 (Jiang et al., 2011) have been shown to effectively alleviate the retinal degenerative phenotype in these mice.

Unlike $r d 1 / r d 1$ mice and GCAP1 mutant mice, accumulation of cGMP in CNG channel deficiency will not lead to elevated intracellular $\mathrm{Ca}^{2+}$ levels. In contrast, cones with CNG channel deficiency may suffer from a lowered $\mathrm{Ca}^{2+}$ due to lack of CNG channel-mediated $\mathrm{Ca}^{2+}$ influx. Hence, the cytotoxicity of cGMP accumulation in $r d 1 / r d 1$ mice and GCAP1 mutant mice strongly depends on high $\mathrm{Ca}^{2+}$ levels, whereas in CNG channel deficiency similar cGMP accumulation cannot cause toxic elevation of cellular $\mathrm{Ca}^{2+}$ levels due to the absence of CNG channels. This argues for the existence of both $\mathrm{Ca}^{2+}$-dependent and $\mathrm{Ca}^{2+}$ independent mechanisms in cGMPrelated cytotoxicity of photoreceptors.

It remains to be determined how accumulation of cGMP per se contributes to photoreceptor degeneration via a mechanism independent of $\mathrm{Ca}^{2+}$ influx through the CNG channel. One possibility could be cytotoxic signaling via cGMP-dependent kinase (PKG). We examined PKG activity and expression levels in the retinas, and found that the enzyme activity and expression level in $\mathrm{Cnga3}^{-1}$ $-; \mathrm{Nrl}^{-1-}$ mice were increased by $\sim 89$ and $24 \%$, respectively, compared with $\mathrm{Nrl}^{-1-}$ controls. We know little about how PKG activity in the channel-deficient retina is regulated at this time but the increased enzyme expression level may contribute at least in part to the observed enzyme's activity measurements. The following two aspects might be associated with the observed increase in PKG activity and expression: (1) chronic accumulation of cGMP exerts an effect on PKG's activity and expression and (2) activation of PKG per se exerts an effect on PKG's activity and expression. It has been shown that PKG phosphorylates and activates the small GTPase Racl (Hou et al., 2004), which indirectly increases cGMP production and hence PKG activity (Guo et al., 2007). Nevertheless, PKG signaling has been shown to contribute to cell death including the rod death in $r d 1 / r d 1$ mice (PaquetDurand et al., 2009), and PKG activation-induced cell death was suggested to be mediated via $\beta$-catenin/TCF signaling (Kwon et al., 2010). The present work shows a significant elevation of PKG activity and expression level in the channel-deficient retina, suggesting that the cGMP-PKG signaling is perhaps involved in cone death. Yet, further investigation is needed to determine whether the PKG signaling contributes to cone death and would be a logical extension of the current work.

In addition to a potential contribution of PKG signaling, metabolic overload and mitochondrial insult may be associated with cGMP accumulation-associated cone death. This is because photoreceptors (Chertov et al., 2011) and cones in particular (Okawa et al., 2008) are among the highest energy consumers of any cell type, and cGMP metabolism is one of the main causes of the energy drain along with maintenance of ionic gradients. Indeed, we have shown the increased levels of mitochondrial apoptotic proteins (including apoptosis inducing factor and endonuclease $\mathrm{G}$ ) in $\mathrm{Cnga3}^{-I-} ; \mathrm{Nrl}^{-1-}$ retinas (Thapa et al., 2012), implying a mitochondrial insult/stress response in CNG channel deficiency.

Our data show that cGMP accumulation is likely caused by low $\mathrm{Ca}^{2+}$ in channel-deficient cones. There was no decrease in PDE6 activity or expression levels in the CNGA3-deficient retinas. If anything, the expression of PDE6C in $\mathrm{Cnga}^{-1-}$; $\mathrm{Nrl}^{-1-}$ retinas was slightly increased, compared with the $\mathrm{Nrl}^{-1-}$ controls, though the maximal PDE activity evoked at direct sunlight did not noticeably change (Fig. $2 A-B$ ). These results do not support a mechanism in which accumulation of 
A

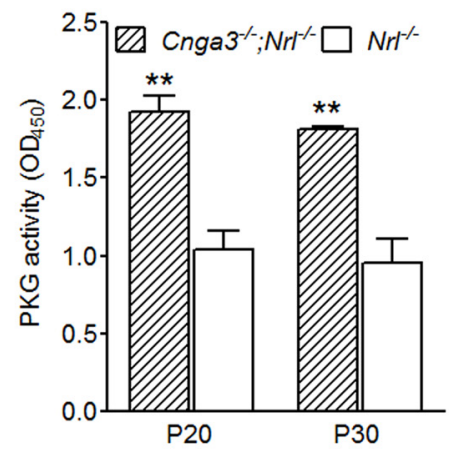

B

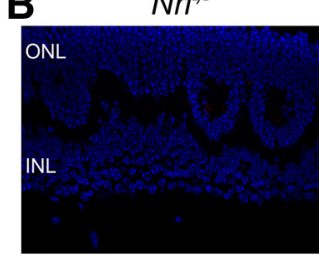

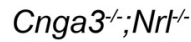

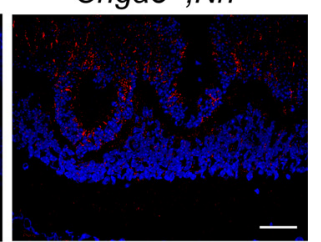

C
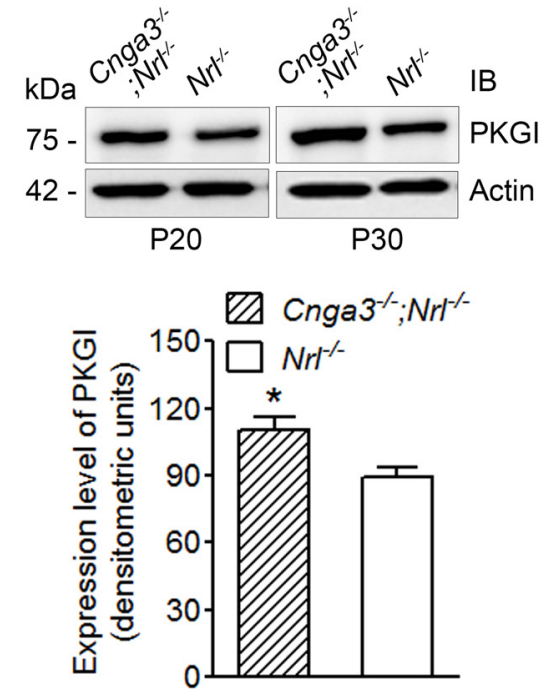

Figure 6. Increased activity and expression of PKG in $\mathrm{Cnga}^{-1-} ; \mathrm{Nrl}^{-1-}$ retinas. A, PKG activity was analyzed using retinal preparations from $\mathrm{Cnga}^{-1-} ; \mathrm{Nrl}^{-1-}$ and $\mathrm{Nrl}^{-1-}$ mice at P2O and P3O by colorimetric analysis. Data are represented as mean \pm SEM three to four assays using retinas prepared from six to eight mice. Unpaired Student's t test was used to evaluate the significances of differences between $\mathrm{Cnga3}^{-1-} ; \mathrm{Nrl}^{-1-}$ and $\mathrm{Nrl}^{-1-}$ mice $\left(^{* *} \mathrm{p}<0.01\right) . \mathbf{B}$, Detection of retinal expression of PKGI in $\mathrm{Cnga}^{-/-} ; \mathrm{Nrl}^{-/-}$and $\mathrm{Nrl}^{-/-}$mice at P3O by immunofluorescence labeling. Shown are representative images of the immunolabeling. ONL, outer nuclear layer; INL, inner nuclear layer. Scale bar, $50 \mu \mathrm{m}$. C, Detection of retinal expression of PKGl in $\mathrm{Cnga3}^{-1-} ; \mathrm{Nrl}^{-/-}$and $\mathrm{Nrl}^{-1-}$ mice by Western immunoblotting (IB). Shown are representative images of the Western immunoblotting at P20 and P30 (top) and the densitometric quantification at P30 (bottom). Data are represented as mean \pm SEM three to four assays using retinas from five to eight mice. Unpaired Student's $t$ test was used to evaluate the significances of differences between $\mathrm{Cnga3}^{-/-} ; \mathrm{Nrl}^{-/-}$and $\mathrm{Nrl}^{-1-}$ mice $\left({ }^{*} \mathrm{p}<0.05\right)$.

cGMP in CNG channel-deficient cones results from inhibition of cGMP hydrolysis by PDE6. Moreover, the total retGC activity not being increased and GCAP1/GCAP2 expression levels being similar in $\mathrm{Cnga3}^{-1-} ; \mathrm{Nrl}^{-1-}$ and $\mathrm{Nrl}^{-1-}$ mice (Fig. 3) argued that the overall catalytic capacity of retGC was not altered enough to account for the dramatic rise in cGMP levels.

We therefore postulate that the lowered cellular $\mathrm{Ca}^{2+}$ levels and, hence, persistent GCAP1-mediated activation of retGC cause a cGMP overproduction in CNG channel-deficient photoreceptors. Combined with the unchanged PDE6 activity this results in the observed accumulation of cGMP in $\mathrm{Cnga3}^{-1-}$ and
$\mathrm{Cnga3}^{-1-} ; \mathrm{Nrl}^{-1-}$ retinas. Loss of functional CNG channel, which is responsible for $\mathrm{Ca}^{2+}$ inflow into the outer segment, decreases free $\mathrm{Ca}^{2+}$ levels in the outer segment, assuming an unchanged function of the exchanger. In mouse rods, shutting down the influx through the CNG channels in the light lowers free cytoplasmic $\mathrm{Ca}^{2+}$ nearly 10-fold (Woodruff et al., 2007), yet the measurement of the intracellular $\mathrm{Ca}^{2+}$ levels in mouse cones has not become technically possible thus far, due to a small size of the cone outer segment. Therefore, the effect of CNG channel deficiency on the levels of free $\mathrm{Ca}^{2+}$ in cones cannot be tested directly. However, we examined the expression level of NCKX2 and found it unchanged between $\mathrm{Cnga3}^{-1-} ; \mathrm{Nrl}^{-1-}$ and $\mathrm{Nrl}^{-1-}$ retinas (Fig. 2C), arguing for a normal efflux of $\mathrm{Ca}^{2+}$. The possibility that the intracellular $\mathrm{Ca}^{2+}$ becomes lowered in CNGA3-deficient cones is also indirectly supported by the observations that the activated forms of inositol trisphosphate receptor $\left(\mathrm{IP}_{3} \mathrm{R}\right)$ and expression of the antiapoptotic protein Bcl-2 both become significantly elevated in $\mathrm{Cnga3}^{-/-} ; \mathrm{Nrl}^{-/-}$retinas (Thapa et al., 2012), likely reflecting a need to compensate for the low levels of $\mathrm{Ca}^{2+}$ by the activation of $\mathrm{IP}_{3} \mathrm{R}$ and Bcl-2-modulated $\mathrm{Ca}^{2+}$ release from endoplasmic reticulum (ER) storage (Palmer et al., 2004).

It needs to be emphasized that the rescue of cone degeneration in $\mathrm{Cnga3}^{-1-}$; Gucy2 $\mathrm{e}^{-1-}$ mice, compared with $\mathrm{Cnga3}^{-1-}$, was only partial. This observation suggests that a cGMP-independent mechanism(s) is also involved. There are several other defects that could potentially contribute to cone death in $\mathrm{Cnga3}^{-1-}$; Gucy $2 e^{-1-}$ mice. First, the cellular $\mathrm{Ca}^{2+}$ level would be still low in $\mathrm{Cnga3}^{-1-}$; Gucy2 $2 e^{-1-}$ cones as that in $\mathrm{Cnga3}^{-1-}$ cones. Could the suppression of $\mathrm{Ca}^{2+}$ influx in CNGA3-deficient cones cause the apoptosis by itself? Low cellular $\mathrm{Ca}^{2+}$ levels have been shown to be harmful to Drosophila photoreceptors (Geng and Pak, 2002) and constantly lowered $\mathrm{Ca}^{2+}$ has been implicated as a possible trigger for rod apoptosis in RPE65-deficient mice (Woodruff et al., 2003). Second, retGC1 activity is known to be required for normal cone protein transport to the outer segment (Baehr et al., 2007) in addition to its role in cGMP biosynthesis. CNG channel deficiency has also been shown to cause impaired opsin trafficking and opsin mislocalization (Michalakis et al., 2005; although this effect could be caused indirectly by the altered cGMP or $\mathrm{Ca}^{2+}$ levels still). Impaired opsin trafficking/opsin mislocalization could potentially cause ER stress and cone death (Thapa et al., 2012). Third, loss of phototransduction in the absence of functional CNG channel per se may contribute to cone death though the mechanism(s) involved remains unknown. Thus, though cGMP production would be suppressed in

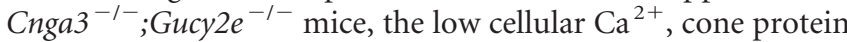
trafficking impairment, and lack of normal cone light response would still adversely affect cone viability.

To conclude, this work shows that cGMP accumulation contributes in part to cone death caused by CNG channel deficiency, and that a higher than normal concentration of cGMP in cones can contribute to cone death not only by its ability to excessively open CNG channels, but also by presently unidentified additional pathways, perhaps involving PKG regulation and cGMP metabolism overload. This work demonstrates that cGMP accumulation in photoreceptors can exert cytotoxicity independent of prolonged opening of CNG channel and excessive $\mathrm{Ca}^{2+}$ influx, providing a new insight into the mechanism of cone degeneration in inherited retinal diseases.

\section{References}

Baehr W, Karan S, Maeda T, Luo DG, Li S, Bronson JD, Watt CB, Yau KW, Frederick JM, Palczewski K (2007) The function of guanylate cyclase 1 and guanylate cyclase 2 in rod and cone photoreceptors. J Biol Chem 282:8837-8847. CrossRef Medline 
Biel M, Seeliger M, Pfeifer A, Kohler K, Gerstner A, Ludwig A, Jaissle G, Fauser S, Zrenner E, Hofmann F (1999) Selective loss of cone function in mice lacking the cyclic nucleotide-gated channel CNG3. Proc Natl Acad Sci U S A 96:7553-7557. CrossRef Medline

Bowes C, Li T, Danciger M, Baxter LC, Applebury ML, Farber DB (1990) Retinal degeneration in the rd mouse is caused by a defect in the beta subunit of rod cGMP-phosphodiesterase. Nature 347:677-680. CrossRef Medline

Chertov AO, Holzhausen L, Kuok IT, Couron D, Parker E, Linton JD, Sadilek M, Sweet IR, Hurley JB (2011) Roles of glucose in photoreceptor survival. J Biol Chem 286:34700-34711. CrossRef Medline

Coleman JE, Zhang Y, Brown GA, Semple-Rowland SL (2004) Cone cell survival and downregulation of GCAP1 protein in the retinas of GC1 knockout mice. Invest Ophthalmol Vis Sci 45:3397-3403. CrossRef Medline

Daniele LL, Lillo C, Lyubarsky AL, Nikonov SS, Philp N, Mears AJ, Swaroop A, Williams DS, Pugh EN Jr (2005) Cone-like morphological, molecular, and electrophysiological features of the photoreceptors of the $\mathrm{Nrl}$ knockout mouse. Invest Ophthalmol Vis Sci 46:2156-2167. CrossRef Medline

Ding XQ, Harry CS, Umino Y, Matveev AV, Fliesler SJ, Barlow RB (2009) Impaired cone function and cone degeneration resulting from CNGB3 deficiency: down-regulation of CNGA3 biosynthesis as a potential mechanism. Hum Mol Genet 18:4770-4780. CrossRef Medline

Dizhoor AM, Lowe DG, Olshevskaya EV, Laura RP, Hurley JB (1994) The human photoreceptor membrane guanylyl cyclase, RetGC, is present in outer segments and is regulated by calcium and a soluble activator. Neuron 12:1345-1352. CrossRef Medline

Farjo R, Skaggs JS, Nagel BA, Quiambao AB, Nash ZA, Fliesler SJ, Naash MI (2006) Retention of function without normal disc morphogenesis occurs in cone but not rod photoreceptors. J Cell Biol 173:59-68. CrossRef Medline

Frasson M, Sahel JA, Fabre M, Simonutti M, Dreyfus H, Picaud S (1999) Retinitis pigmentosa: rod photoreceptor rescue by a calcium-channel blocker in the rd mouse. Nat Med 5:1183-1187. CrossRef Medline

Gamm DM, Barthel LK, Raymond PA, Uhler MD (2000) Localization of cGMP-dependent protein kinase isoforms in mouse eye. Invest Ophthalmol Vis Sci 41:2766-2773. Medline

Geng C, Pak WL (2002) Photoreceptor degeneration and $\mathrm{Ca}^{2+}$ influx through light-activated channels of Drosophila. Adv Exp Med Biol 514: 585-599. CrossRef Medline

Guo D, Tan YC, Wang D, Madhusoodanan KS, Zheng Y, Maack T, Zhang JJ, Huang XY (2007) A Rac-cGMP signaling pathway. Cell 128:341-355. CrossRef Medline

Hofmann F, Feil R, Kleppisch T, Schlossmann J (2006) Function of cGMP-dependent protein kinases as revealed by gene deletion. Physiol Rev 86:1-23. CrossRef Medline

Hou Y, Ye RD, Browning DD (2004) Activation of the small GTPase Rac1 by cGMP-dependent protein kinase. Cell Signal 16:1061-1069. CrossRef Medline

Jiang L, Zhang H, Dizhoor AM, Boye SE, Hauswirth WW, Frederick JM, Baehr W (2011) Long-term RNA interference gene therapy in a dominant retinitis pigmentosa mouse model. Proc Natl Acad Sci U S A 108: 18476-18481. CrossRef Medline

Kaupp UB, Seifert R (2002) Cyclic nucleotide-gated ion channels. Physiol Rev 82:769-824. Medline

Kohl S, Marx T, Giddings I, Jägle H, Jacobson SG, Apfelstedt-Sylla E, Zrenner E, Sharpe LT, Wissinger B (1998) Total colourblindness is caused by mutations in the gene encoding the alpha-subunit of the cone photoreceptor cGMP-gated cation channel. Nat Genet 19:257-259. CrossRef Medline

Kwon IK, Wang R, Thangaraju M, Shuang H, Liu K, Dashwood R, Dulin N, Ganapathy V, Browning DD (2010) PKG inhibits TCF signaling in colon cancer cells by blocking beta-catenin expression and activating FOXO4. Oncogene 29:3423-3434. CrossRef Medline

Lolley RN, Schmidt SY, Farber DB (1974) Alterations in cyclic AMP metabolism associated with photoreceptor cell degeneration in the $\mathrm{C} 3 \mathrm{H}$ mouse. J Neurochem 22:701-707. CrossRef Medline

Lowe DG, Dizhoor AM, Liu K, Gu Q, Spencer M, Laura R, Lu L, Hurley JB (1995) Cloning and expression of a second photoreceptor-specific membrane retina guanylyl cyclase (RetGC), RetGC-2. Proc Natl Acad Sci U S A 92:5535-5539. CrossRef Medline
Makino CL, Peshenko IV, Wen XH, Olshevskaya EV, Barrett R, Dizhoor AM (2008) A role for GCAP2 in regulating the photoresponse. Guanylyl cyclase activation and rod electrophysiology in GUCA1B knock-out mice. J Biol Chem 283:29135-29143. CrossRef Medline

Matveev AV, Quiambao AB, Browning Fitzgerald J, Ding XQ (2008) Native cone photoreceptor cyclic nucleotide-gated channel is a heterotetrameric complex comprising both CNGA3 and CNGB3: a study using the conedominant retina of $\mathrm{Nrl}^{-/-}$mice. J Neurochem 106:2042-2055. Medline

Mears AJ, Kondo M, Swain PK, Takada Y, Bush RA, Saunders TL, Sieving PA, Swaroop A (2001) $\mathrm{Nrl}$ is required for rod photoreceptor development. Nat Genet 29:447-452. CrossRef Medline

Michalakis S, Geiger H, Haverkamp S, Hofmann F, Gerstner A, Biel M (2005) Impaired opsin targeting and cone photoreceptor migration in the retina of mice lacking the cyclic nucleotide-gated channel CNGA3. Invest Ophthalmol Vis Sci 46:1516-1524. CrossRef Medline

Michalakis S, Mühlfriedel R, Tanimoto N, Krishnamoorthy V, Koch S, Fischer MD, Becirovic E, Bai L, Huber G, Beck SC, Fahl E, Büning H, Paquet-Durand F, Zong X, Gollisch T, Biel M, Seeliger MW (2010) Restoration of cone vision in the $C N G A 3^{-/-}$mouse model of congenital complete lack of cone photoreceptor function. Mol Ther 18:2057-2063. CrossRef Medline

Nikonov SS, Daniele LL, Zhu X, Craft CM, Swaroop A, Pugh EN Jr (2005) Photoreceptors of $\mathrm{Nrl}^{-1-}$ mice coexpress functional S- and M-cone opsins having distinct inactivation mechanisms. J Gen Physiol 125:287-304. CrossRef Medline

Okawa H, Sampath AP, Laughlin SB, Fain GL (2008) ATP consumption by mammalian rod photoreceptors in darkness and in light. Curr Biol 18: 1917-1921. CrossRef Medline

Olshevskaya EV, Calvert PD, Woodruff ML, Peshenko IV, Savchenko AB, Makino CL, Ho YS, Fain GL, Dizhoor AM (2004) The Y99C mutation in guanylyl cyclase-activating protein 1 increases intracellular $\mathrm{Ca}^{2+}$ and causes photoreceptor degeneration in transgenic mice. J Neurosci 24: 6078-6085. CrossRef Medline

Olshevskaya EV, Peshenko IV, Savchenko AB, Dizhoor AM (2012) Retinal guanylyl cyclase isozyme 1 is the preferential in vivo target for constitutively active GCAP1 mutants causing congenital degeneration of photoreceptors. J Neurosci 32:7208-7217. CrossRef Medline

Palmer AE, Jin C, Reed JC, Tsien RY (2004) Bcl-2-mediated alterations in endoplasmic reticulum $\mathrm{Ca}^{2+}$ analyzed with an improved genetically encoded fluorescent sensor. Proc Natl Acad Sci U S A 101:17404-17409. CrossRef Medline

Paquet-Durand F, Hauck SM, van Veen T, Ueffing M, Ekström P (2009) PKG activity causes photoreceptor cell death in two retinitis pigmentosa models. J Neurochem 108:796-810. CrossRef Medline

Paquet-Durand F, Beck S, Michalakis S, Goldmann T, Huber G, Mühlfriedel R, Trifunović D, Fischer MD, Fahl E, Duetsch G, Becirovic E, Wolfrum U, van Veen T, Biel M, Tanimoto N, Seeliger MW (2011) A key role for cyclic nucleotide gated (CNG) channels in cGMP-related retinitis pigmentosa. Hum Mol Genet 20:941-947. CrossRef Medline

Thapa A, Morris L, Xu J, Ma H, Michalakis S, Biel M, Ding XQ (2012) Endoplasmic reticulum stress-associated cone photoreceptor degeneration in cyclic nucleotide-gated channel deficiency. J Biol Chem 287: 18018-18029. CrossRef Medline

Thiadens AA, Somervuo V, van den Born LI, Roosing S, van Schooneveld MJ, Kuijpers RW, van Moll-Ramirez N, Cremers FP, Hoyng CB, Klaver CC (2010) Progressive loss of cones in achromatopsia. An imaging study using spectral-domain optical coherence tomography. Invest Ophthalmol Vis Sci 51:5952-5957. CrossRef Medline

Weiss ER, Hao Y, Dickerson CD, Osawa S, Shi W, Zhang L, Wong F (1995) Altered cAMP levels in retinas from transgenic mice expressing a rhodopsin mutant. Biochem Biophys Res Commun 216:755-761. CrossRef Medline

Woodruff ML, Wang Z, Chung HY, Redmond TM, Fain GL, Lem J (2003) Spontaneous activity of opsin apoprotein is a cause of Leber congenital amaurosis. Nat Genet 35:158-164. CrossRef Medline

Woodruff ML, Olshevskaya EV, Savchenko AB, Peshenko IV, Barrett R, Bush RA, Sieving PA, Fain GL, Dizhoor AM (2007) Constitutive excitation by Gly90Asp rhodopsin rescues rods from degeneration caused by elevated production of cGMP in the dark. J Neurosci 27:8805-8815. CrossRef Medline

Xu J, Morris L, Fliesler SJ, Sherry DM, Ding XQ (2011) Early-onset, slow progression of cone photoreceptor dysfunction and degeneration in 
CNG channel subunit CNGB3 deficiency. Invest Ophthalmol Vis Sci 52:3557-3566. CrossRef Medline

Yang RB, Robinson SW, Xiong WH, Yau KW, Birch DG, Garbers DL (1999) Disruption of a retinal guanylyl cyclase gene leads to cone-specific dystrophy and paradoxical rod behavior. J Neurosci 19:5889-5897. Medline
Yoshida S, Mears AJ, Friedman JS, Carter T, He S, Oh E, Jing Y, Farjo R, Fleury G, Barlow C, Hero AO, Swaroop A (2004) Expression profiling of the developing and mature $\mathrm{Nrl}^{-1-}$ mouse retina: identification of retinal disease candidates and transcriptional regulatory targets of Nrl. Hum Mol Genet 13:1487-1503. CrossRef Medline 